\title{
The Impact Of Integration, Affirmative Action, And Diversity On Minority Student Recruitment At The University Of Alabama: A Longitudinal Perspective
}

John L. Festervand, (E-mail: jfestervand@bama.ua.edu), Student, University of Alabama Troy A. Festervand, Middle Tennessee State University

\begin{abstract}
This paper explores the University of Alabama's positions, actions, policies, and accomplishments over the past forty years with respect to minority representation among its students and faculty. The impact and progression of these initiatives by the University of Alabama demonstrates strides have been made. The paper also examines the University's recruiting efforts to attract more minority faculty and students. The transition from integration to affirmative action to diversity in higher education also are examined.
\end{abstract}

\section{INTRODUCTION}

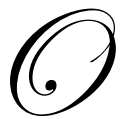

n June 11, 1963, Calvin Hanna was a thirty-four year old photographer for the Tuscaloosa News. Despite his youth and limited experience, Mr. Hanna became responsible for one of photojournalism's most enduring and defining moments (see Attachment A). On that day, then Governor George C. Wallace took his stand against the integration of the University of Alabama. Hanna's photographic recording of that historical event became known around the world as Wallace's "stand in the schoolhouse door" and for many, was the personification of southern racism.

While Governor Wallace's actions were directed toward Vivian J. Malone and James A. Hood, they were temporally misdirected at a minimum, as Ms. Malone and Mr. Hood were not the first African Americans to be enrolled at the University of Alabama. On February 3, 1956, Autherine Juanita Lucy, born October 5, 1929, to Minnie and Milton Lucy of Shiloh, Alabama, was admitted to the University of Alabama as a graduate student in library science. Her ambition was to have the best education possible. However, after her third day of class, she was suspended from the university. It was not until April of 1988, that the University of Alabama's Board of Governors overturned her suspension. In 1992, Autherine Juanita Lucy graduated from the University of Alabama with a Master's Degree in Elementary Education (Pruitt, 2003). Today, a portrait of her hangs in the University's Ferguson Center with an inscription that reads "her initiative and courage won the right for students of all races to attend the university."

Some fifty years later, minority students of all colors and from all corners of the globe can be seen traversing the University's campus. There is no National Guard on duty ensuring the safety of all. There are no crosses burning or shouts of violence. There are lots of mobs, but most of those are found on game day in the "Quad." Indeed, while it has taken time to bring about socio-cultural change, such change has taken place and continues to take place on the campus of the University of Alabama and other institutions of higher learning.

For example, University of Alabama Senior, Jenae Michelle Staples, is from Fairfield, Alabama, and is President of the University's Chapter of the NAACP. She chose the University of Alabama for three reasons. "I had an aunt that graduated from the Capstone College of Nursing and she loved Alabama when she was here." According to 
Staples, "Alabama has a very good nutrition program and that is what I wanted to major in since I was in high school." Finally, Staples chose the University of Alabama because "when I came down here, I loved it as I met people and I feel like the University is what you make it" (see Attachment B).

While the preceding paragraphs describe opposite ends of the academic, social, cultural, and philosophical landscape that typifies the period from the mid-1960's until today, what took place between these points in time is the purpose of this research effort. More specifically, this research explores the University of Alabama's positions, actions, policies, and accomplishments, with respect to minority representation, over the past forty years.

\section{HIGHER EDUCATION'S TRANSITION FROM INTEGRATION TO AFFIRMATIVE ACTION, TO DIVERSITY}

Minorities have struggled for decades to achieve equality in access to both public and private higher education. These struggles were supposed to be ameliorated by the landmark decision, Brown vs. Board of Education of Topeka (Brown I, 1954), which declared racial segregation in public schools unconstitutional. Likewise, the second Brown decision, Brown v. Board of Education of Topeka (Brown II, 1955), instructed the affected school districts to comply with the Supreme Court decision (Kluger, 1975).

In 1955, Lucy v. Adams became the first higher education case decided by the Supreme Court. This case involved Autherine Lucy and her attempt to enroll in graduate school at the University of Alabama. The court ruled in favor of Autherine Lucy (Lucy v. Adams, 1955). This case demonstrated that the desegregation decision in Brown v. Board of Education of Topeka applied to higher education as well. Additionally, the decision communicated that constitutional rulings regarding public schools may also be applicable to colleges and universities, thus setting the legal stage for the integration of higher education (Miles, 1997).

Despite legal precedent, minority involvement and enrollment in higher education made little progress through the 1950's and 1960's, especially in the south as evidenced by Governor George Wallace's stand against integration at the University of Alabama. Immediately following this historical event, President John F. Kennedy reported to the American people on the state of civil rights in the nation. He called on Congress to pass legislation dismantling the system of segregation and encouraged lawmakers to make a commitment "to the proposition that race has no place in American life or law" (Canady, 1998).

Academic research from the 1960's that focused on integration in higher education often focused on problems, as opposed to solutions. For example, Egerton (1969) surveyed eighty predominantly white state and land grant institutions regarding racial composition. The resulting report detailed case studies of five selected universities and identified some problems faced by the institutions, as well as some of the programs that offered promise for increasing educational opportunity. The University of Alabama was one of the universities studied. Two conclusions resulted: (1) black militants and radical whites in the university appear to have little in common, and (2) the idea of a black monolith is a myth. Further the research found that Black Americans who were involved in issues of educational reform, varied in personality, philosophy, and style.

Three surveys, specific to the University of Alabama from its desegregation in 1963 until 1969, provided an assessment of initial changes in the integration attitudes of deep-South university students. Muir (1970) found rapidly increasing acceptance of blacks was found in the four major areas examined: general societal areas of conflict, social distance on campus, perception of Negro characteristics, and attitudes regarding political and economic equality. The student majority, accepting "separate but equal" segregation in 1963, approved desegregation in 1969. The majority of these students had not yet accepted "social integration," but strong trends in this direction were evident.

Muir (1974), in later surveys of white student's attitudes on the main campus of the University of Alabama, begun in 1963 and continued at 3-year intervals, indicated increasing acceptance of blacks. It appeared that the desegregation of any social system resulted in the rapid rejection of "racial" roles. 
While the foundation for the integration of higher education was established in the 1960's, very little progress was achieved. For example, a 1968 survey of eighty predominantly white state and land-grant colleges revealed that in those institutions, less than two of every one hundred students, one of every one hundred graduates, and one of every one hundred faculty members were black Americans (Egerton, 1969). However, institutions of higher learning were about to experience a radical change as Affirmative Action became the new operating standard.

Affirmative action has been defined as specific actions in recruitment, hiring, upgrading and other areas designed and taken for the purpose of eliminating the present effects of past discrimination, or to prevent discrimination (Giles, 2005). According to the 2005 edition of the Stanford Encyclopedia of Philosophy, "affirmative action means positive steps taken to increase the representation of women and minorities in areas of employment, education, and business from which they have been historically excluded." Because these steps, in the minds of many, involved preferential selection - selection on the basis of race, gender, or ethnicity - affirmative action has generated intense controversy.

The phrase "affirmative action" was first used in President Lyndon Johnson's 1965 Executive Order 11246, which requires federal contractors to "take affirmative action to ensure that applicants are employed, and that employees are treated during employment, without regard to their race, creed, color, or national origin." According to Sykes (1995), the goal of affirmative action was not merely about political correctness, rather, it was to give students the opportunity to learn from a wide variety of peers so that in the future they could understand the diversity of the people with whom they would need to interact, and thereby to display wisdom they might not otherwise have and was/is based on a three-fold premise.

Affirmative action's development has proceeded along two paths. One has been legal and administrative as courts, legislatures, and executive departments of government have made and applied rules requiring affirmative action. The other has been the path of public debate, where the practice of preferential treatment has spawned a vast literature, pro and con. Often enough, the two paths have failed to make adequate contact, with the public quarrels not always very securely anchored in any existing legal basis or practice.

In its modern form, affirmative action may require for an admissions officer faced with two similarly qualified applicants to choose the minority over the white, or for a manager to recruit and hire a qualified woman for a job instead of a man. Affirmative action decisions are generally not supposed to be based on quotas, nor are they supposed to give any preference to unqualified candidates or harm anyone through reverse discrimination (Froomkin, 1998).

Affirmative action opponents argue that student/employee selection should be based upon merit with the most meritorious candidate having a right to the position. Race is a bona fide qualification for a job only in special circumstances. Sykes (1995) argues that the problem with using merit-based approaches has been that certain groups consistently perform poorly on traditional admission tests. In practice, race-based affirmative action will open opportunities to minorities and women at the expense of the least advantaged white men (Walzer, 1983).

Legislation passed in California in 1996 to end preferences based on gender and race gives rise to reflections on the moral foundations and effectiveness of the civil rights movement. According to Canady (1998), the endorsement of preferences led the civil rights movement down a path to legalized discrimination and eroded its moral authority in the eyes of many Americans In a series of cases, the Supreme Court has made it clear that such a preferential system based upon racial classifications are presumptively unconstitutional and will be permitted only in extraordinary circumstances (Davis, 2004).

The University of Alabama's Office of Equal Opportunity Programs operates under the guidance of Gwendolyn D. Hood, Director and University Compliance Officer. A complete listing of the University's Equal Opportunity Policies, as well as official guidelines for the faculty search and appointment process can be found at http://eop.ua.edu/policies.html. 
Following the 2003 Supreme Court rulings on affirmative action, a strong sense of relief prevailed on college campuses that advocated for diversity in higher education. However, this sense of relief was mitigated by the diminution of benefits purported to be associated with diversity. In addition to far-ranging changes in student and faculty diversity, the positive impact of multiculturalism was seen in the design of new courses and the emergence of new social relations on university campuses (Katz and O'Leary, 2002). Similarly, Gurin, Dey, Hurtado, and Gurin (2005) argue diversity in the college setting contributes to a student's academic and social growth, as well as increasing access to higher education for minorities.

In a 1998 campus climate for diversity survey of a major research university in the southern U.S, Brown (2004) addressed the issue of diversity in higher education, and argued that the diversification of the faculty and student population can no longer be a peripheral activity, but must be reflective of the institution's commitment to diversity. Brown concluded that institutions of higher education do not only have a responsibility, but must assume leadership position on this crucial issue of preparing citizens for the world they now face.

However, while the challenges of meeting the needs of diverse students and faculty have long been recognized in higher education, many institutions wrestle with meager budgets. This climate of frugality conflicts mightily with an increasingly diverse student body (Marcy, 2004). Building upon this theme, Jones (2003) argued that a state of financial exigency in many universities may limit faculty diversification activities. While perhaps more applicable to many small and mid-sized universities, larger institutions often are able to commit large sums of money to the student/faculty diversification effort (Lawler, 2005).

Many colleges and universities purport to desire racial diversity, yet few make considerable progress in this regard. In addressing this dubious progress, Davis (2002) compared colleges/universities that have achieved relatively high percentages of African American and Latino American students and faculty to those with low percentages. At the successful schools, more people participated in diversity efforts, and administrators more often had the time, mandate, and power to be effective. Davis also found that successful schools employed a wider variety of affirmative action practices, and these practices were proactive, involved persons of color, included curriculum and co-curriculum intervention, and addressed underlying problems. Finally, the campus climate at the successful schools offered greater support for racial diversity.

In addressing the paucity of faculty/student diversity at many institutions, Cherwitz (2004) offered an unusual, but informative perspective regarding the lack of campus diversity. Cherwitz argued that it is not predominantly the admissions process that accounts for the dearth of minority students in graduate school, but the lack of a substantial minority applicant pool that prevents more than incremental progress toward diversity.

Citing statistics from the University of Texas, in Fall 2003, only 6.3 percent of the 18,000-plus applicants to UT's graduate school were Hispanic, African American, or Native American. Furthermore, 60 percent of these minority applicants were in less than 20 percent of the institution's available degree programs. Cherwitz concluded that while adjusting the admissions process and offering additional scholarships and fellowships might make some difference, no profound increase in diversity will occur until significant progress is made in convincing talented minorities to pursue graduate study. Cherwitz also noted that "nationally, top-notch graduate institutions play numbers games, waging war with each other to redistribute an already undersized minority applicant population and then declaring victory when statistically insignificant gains are made."

Diversity at the University of Alabama is evident at almost every turn and in every academic unit. The University's commitment to diversity was made abundantly clear by Pat Bauch, Department of Educational Leadership in the College of Education, who on September 29, 2004, in addressing the President's Advisory Council on Diversity stated:

Given the legacy of racism that we have inherited, particularly through the misnamed George Wallace's Stand in the School House Door, we believe that this campus should become a showcase for other institutions of higher education by assuring that we are free of hatred, name-calling, gay-bashing, racial exclusion and the political white influence of The Machine that has long dominated our campus assuring that power remains in the hands of a few. 


\section{RESEARCH METHODOLOGY}

As previously noted, the objective of this research is to explore the University of Alabama's positions, actions, policies, and accomplishments, with respect to minority representation, over the past forty years. The research employed both secondary and primary research. Secondary research was used to establish the existing body of knowledge related to diversification in higher education. Secondary research also was used to identify student and faculty demographic composition at the University of Alabama during the study period.

Because a limited amount of secondary information was available with which to identify specific diversification strategies, plans, actions, etc. put in place by the university's administration during the study period, primary research in the form of personal interviews with university officials familiar with such strategies, plans, actions, etc. was conducted.

\section{FINDINGS}

The findings of this research effort are presented as two separate, yet interrelated parts. First, a timeline of the University's multicultural accomplishments is presented. This timeline represents a chronological listing of representative accomplishments that have occurred over the past forty years. While reflective of individual and university accomplishments, the events and persons presented are only a sample of the many such accomplishments that have been achieved.

The second part of the research findings will present data on minority student enrollment at the University. Insight gleaned from interviews with select university officials is integrated into the presentation of these data.

\section{A Timeline Of Multi-Cultural Accomplishments}

1963 Donald Wilbur Stewart served as SGA President during the integration period at the University. Mr. Stewart went on to serve as a United States Senator and is now an attorney in Anniston, AL.

1966 Dr. Joffre T. Whisenton became the first African-American doctoral student to earn a Ph.D. from the University. Dr. Whisenton is now a higher education consultant based in Atlanta.

1968 The African American Association (AAA) was created and was renamed the Black Student Union (BSU) in 2005.

1969 Wendell Thomas Hudson became the first African-American student-athlete to receive a scholarship to the University for men's basketball. Mr. Hudson is now the athletic director for McLennan Community College in Waco, Texas.

1970 Wilbur Jackson became the first African-American student-athlete to receive a scholarship to the University to play football with the Crimson Tide. Mr. Jackson is today a businessman in Ozark, Alabama.

1971 The Black Faculty and Staff Association (BFSA) was established this year.

1972 John Mitchell Jr. became the first black All-American football player to play for the Crimson Tide. Mitchell is now in his $32^{\text {nd }}$ season coaching, including 16 years at the college level, 2 years in the United States Football League, and 15 years as an NFL coach.

1973 Brenda McCampbell Lyons became the first African-American cheerleader, who later went on to become a school administrator

1974 Alpha Kappa Alpha (AKA) Sorority, Alpha Phi Alpha (AФA) Fraternity, Delta Sigma Theta $(\Delta \Sigma \Theta)$ Sorority,

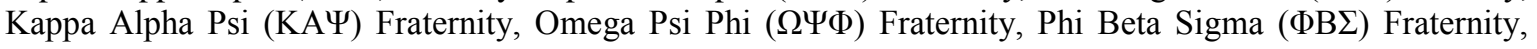
Sigma Gamma Rho ( $\Sigma \Gamma P)$ Sorority, and Zeta Phi Beta (ZథB) Sorority were all founded.

1975 Sylvester Jones became the first African-American executive vice president of the SGA and student representative to the UA board of trustees. The Sylvester Jones Leadership and Career Resource Center is named in memory of Mr. Jones, who passed away in 1997.

1976 Cleophus Thomas Jr. became the UA's first and, thus far, only African-American SGA president. Mr. Thomas is a trustee emeritus in the University system, an attorney, and Chairman and Chief Executive Officer of the A.G. Gaston Corporation, Birmingham, AL.

1980 The Black Law Students Association was established. 
1982 The first Minority Journalism Workshop was conducted in 1984, beginning 20 years of outstanding success by the program. This effort was the idea of Professor Marian Huttensine and then graduate student Marie Parsons, who then worked to recruit and develop minority students for careers in journalism.

1984 National Society of Black Engineers (NSBE) was established, as was Minorities for Careers in Communication (becomes Capstone Association of Black Journalist in 1993).

1985 National Pan-Hellenic Council (NPHC) and the National Association for the Advancement of Colored People (NAACP) were established.

1987 The Multicultural Engineering Program (MEP) was established. With the establishment of the UA's MEP, improvements in student recruitment and retention remained a high priority.

1991 The Department of American Studies began offering a minor in African-American studies under the guidance of a committee of UA faculty.

1997 The African-American Studies Program was officially established. African-American Studies is an interdisciplinary program of study whose objectives are to foster a wider understanding of African Americans and to introduce methods appropriate to interdisciplinary cultural studies.

1998 National Council of Colored Women was established.

2004 President Witt announced the creation of a Vice President for Community Affairs and charged that administrative unit with, among other things, fostering a welcoming and inclusive campus environment by providing leadership in the areas of diversity, inclusiveness, equal opportunity, and equity.

What do these, and the many other multicultural accomplishments at the University of Alabama connote? Perhaps that question can best be answered by the University President Witt. In numerous memoranda to the campus community, President Whitt continuously reaffirms the University's mission of educating a diverse population and its support for "policies, programs, events, and co-curricular activities that enhance awareness and appreciation of cultural and individual diversity, promote community, and encourage full participation of all members and groups in every aspect of University life." The President urged the University community to endorse "equity of opportunity" as one of the University's most important goals. Further, the President pledged the University's commitment to cultivating "a hospitable campus environment in which all members of the University can work together and learn from each other in a climate of mutual respect." Likewise, the University's commitment to diversity was best reflected in comments made by the President to the Alabama Legislative Black Caucus in April of 2005:

As the state's flagship university, we understand our leadership role in improving race relations in our state and take seriously our mission of teaching, research and service to ALL Alabamians. We remain committed to improving minority student recruitment and retention, to achieving greater diversity among our faculty and staff, and continuing to foster an environment of inclusiveness for all students, alumni, faculty and staff.

\section{Minority Student Enrollment}

While the preceding accomplishments and statements from the University's leadership speak volumes about the University's past, present, and future with regard to multiculturalism, actual data in these areas provides the most accurate assessment of the progress that has been achieved. Figure 1 presents data on minority student enrollment.

With regard to minority student enrollment, the University has witnessed modest, consistent growth in the past twenty-five years. As Figure 2 indicates, it was not until the early 1970's that minority enrollment accelerated. In large part, early gains were minimal as most southern universities struggled to accept and respond to forced integration. However, with the arrival of Affirmative Action, the University launched a series of initiative that allowed it to expand its minority student enrollment. These gains accelerated even more as various diversity initiatives were put in place. 
Figure 1: Minority Student Enrollment

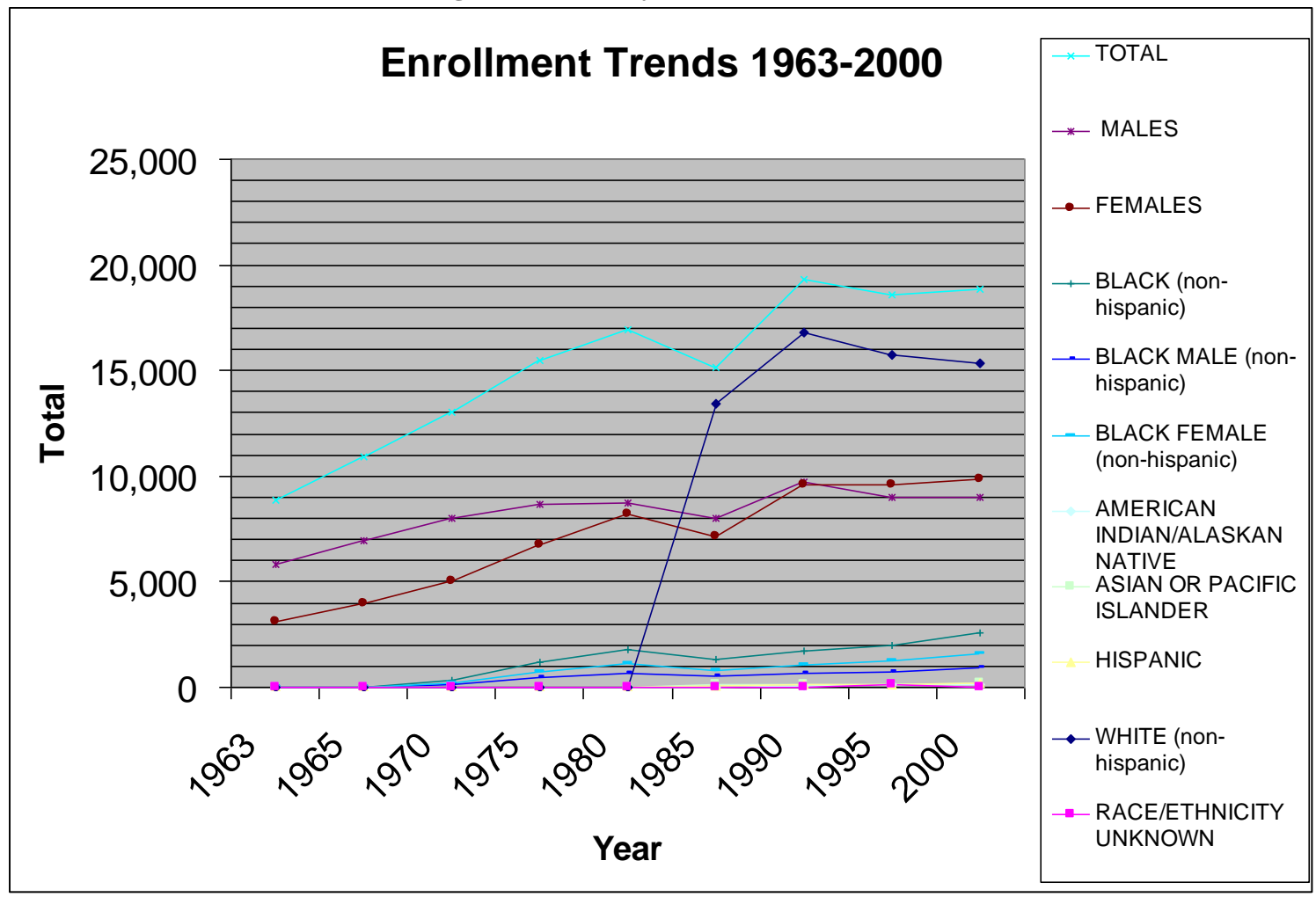

Based upon interviews conducted, increases in minority enrollment were achieved in a variety of ways. Initially, the University used advertisements in minority publications, focused recruiting efforts, and promotional materials to attract minority students. These efforts proved largely unsuccessful. These early efforts to attract minority students failed because the students immediately recognized the insincerity of the effort.

Following these initial recruiting efforts, a strategic decision was made. That decision required the University to make a commitment to the recruitment and retention of minority candidates. While limited in number and scope, early programs were developed and put in place. Such programs included the hiring of minority recruiters, advisors, and faculty, as well as recruiting efforts that went directly into the schools and homes of potential students.

Today, the University's minority student recruiting and retention activities are too numerous to mention, but include curriculum changes, institutional changes, faculty/staff changes, programmatic changes, increased support funding, mentors, associations, college specific initiatives, and many others. These efforts have allowed, and continue to allow, a minority student at the University of Alabama to access a support network that can enrich his/her academic experience. Further, such efforts carry well beyond the time the student spends at the University. The University's minority graduates are regarded as one of its greatest assets and recruiting tools.

\section{CONCLUSIONS}

For many colleges and universities, especially those in the south, the changes brought about by the Civil Rights Movement proved extremely difficult. The social implications associated with the movement created an environment fraught with anxiety, hatred, and resentment. As chronicled in this paper, the changes that resulted required substantial time, energy, and resources, but are today considered glowing achievements. 
Perhaps at no other institution were the costs greater than at the University of Alabama. Likewise, at no institution of higher learning are these changes more evident today. The University has distinguished itself nationally, if not globally, by assuming a leadership role in attracting and retaining qualified minority students and faculty.

While these accomplishments were the result of many factors, at the foundation of institutional change was the commitment made by the University's leadership to move the forward. University leaders, both administration and faculty, joined ranks and created a social and academic model that encouraged academic excellence, as well as academic inclusion. Examples of these efforts are chronicled in this paper.

As the University continues to move forward, it must recognize its past, revel in its presence, and plan for the future. That challenge can best be met with all members of the University family working together to build a better tomorrow.

\section{REFERENCES}

1. Brown v. Board of Education of Topeka Kansas. (1954). Brown I, 347, U.S. 483, 15, 17.

2. Brown v. Board of Education of Topeka Kansas .(1955). Brown II, 349, U.S. 294, 15, 17.

3. Brown, L. Diversity: the challenge for higher education. Race, Ethnicity and Education 7.1 (March 2004): 21(14).

4. Canady, Charles T. (Jan-Feb 1998 n87) America's struggle for racial equality. In Policy Review, p42 (6).

5. Cherwitz, Richard A. Capitalizing on unintended consequences: lessons on diversity from Texas. (Reality Check). Peer Review 6.3 (Spring 2004): 33(3).

6. Clark, E.C. (1993). The school house door: Segregation's last stand at the University of Alabama. New York: Oxford University

7. Davis, Henry Vance. (Summer 2004)Forced into glory: the destruction of Grutter v. Lee Bollinger et al. In The Black Scholar, 34, p30-37.

8. Davis, L.R. Racial Diversity in Higher Education: Ingredients for Success and Failure. Journal of Applied Behavioral Sciences 38.2 (June 1, 2002): 137(19).

9. Egerton, John, State Universities and Black Americans: An Inquiry into Desegregation and Equity for Negroes in 100 Public Universities, 1969.

10. Froomkin, Dan, Affirmative Action Under Attack, Washington Post, October 1998, http:/www.washingtonpost.com/wp-srv/politics/special/affirm/affirm.htm.

11. Fullinwider, Robert, Affirmative Action, The Stanford Encyclopedia of Philosophy (Spring 2005 Edition), Edward N. Zalta (ed.), http://plato.stanford.edu/archives/spr2005/entries/affirmative-action/>Giles, Robert E. (2005). Office of Affirmative Action, Equal Opportunity, and Diversity. Retrieved November 16, 2005 from the University of Rode Island, glossary of affirmative action terms: http://www.uri.edu/affirmative_action/definitions.html

12. Gurin, Patricia; Dey, Eric L.; Hurtado, Sylvia; and Gurin, Gerald. Diversity and higher education: theory and impact on educational outcomes. Harvard Educational Review 72.3 (Fall 2002): 330-366.

13. Heise, Michael. (Jan 2005)Brown v. Board of Education, footnote 11, and multidisciplinary. (Revisiting Brown v. Board of Education: 50 Years of Legal and Social Debate). In Cornell Law Review, 90, p279-320.

14. Johnson, Lyndon http://dol.gov/esa/regs/statutes/ofccp/eo11246.htm

15. Katz, Susan Roberta, \& O'Leary, Cecilia Elizabeth. (Winter 2002)Overview of new pedagogies for social change.(Editorial). In Social Justice, 29, p1(7).

16. Kennedy, John, 1961, http://www.infoplease.com/spot/affirmativetimeline1.html

17. Kluger, R. (1975). Simple justice. New York: Vintage Books/A Division of Random House.

18. Knight v. the state of Alabama. (1991). 787 Federal Supplement 1030 Northern District of Alabama.

19. Lawler, Andrew. Harvard pledges $\$ 50$ million to boost diversity on campus.(Higher Education). Science 308.5725 (May 20, 2005): 1102(1).

20. Lucy v. Adams. (1955). 350, U.S. 1, 16.

21. Marcy, M.B. When Diversity and Dollars Collide: Challenges for Higher Education. Innovative Higher Education 28.3 (Annual 2004): 205(14).

22. Miles, A. (1997). College law ( $2^{\text {nd }}$ ed.). Northport, Al: SEVGO Press. 
23. Muir, Donald E. (1970), Six-year trends in integration, attitudes of deep South university students, Integrated Education: Race and Schools, v. 9, (January 1971), p.21-27.

24. Muir, Donald E. (1974), Through the school house door: Trends in integration, attitudes on a deep South campus during the first decade of desegregation, Sociology and Social Research, v. 58, 2 (January 1974), p.113-121.

25. Rowan, C. (1993). Dream makers, dream breakers: The world of Justice Thurgood Marshall. Toronto, Canada: Little \& Brown Company.

26. Sternberg, Robert J. (Jan-Feb 2005)Accomplishing the goals of affirmative action--with or without affirmative action. Change, 37, p6(8).

27. Sykes, Marquita, The Origins of Affirmative Action, http:/www.now.org/nnt/08-95/affirmhs.html

28. Walzer, Michael. Spheres of Justice. (NewYork: Basic Books, 1983), pp. 143-154.

29. The United States Constitution. (Proposed 1866) (Revised 1868). The $14^{\text {th }}$ Amendment of the U.S. Constitution. Retrieved November 16, 2005 from: http://www.usconstitution.net/xconst_Am14.html 


\section{NOTES}

